\title{
木質鋼板単体ボルト接合の繊維方向荷重に対する強度算定法の提案 A STRENGTH CALCULATION METHOD OF SINGLE BOLTED TIMBER JOINT LOADED PARALLEL TO THE GRAIN
}

\author{
野口昌宏*, 坂田弘安**, 和田章***, 宮澤健二**** \\ Masahiro NOGUCHI, Hiroyasu SAKATA, Akira WADA \\ and Kenji MIYAZAWA
}

\begin{abstract}
We, in this article, propose a manual strength calculation method of single bolted timber joint loaded parallel to the grain. The strength calculation method takes into account the edge distance, the end distance, and the slenderness ratio as the parameters. The validity of the proposed calculation method was confirmed by the experimental results, the edge distance of $1 d, 2 d, 4 d, 6 d, 7 d$, the end distance of $1 d, 2.5 d, 4 d, 7 d, 10 d$, the slenderness ratio of $0.625 d, 3.75 d$, $7.5 d, 10 d$.
\end{abstract}

Keywords : Strength calculation method, Bolted timber joint, Loading parallel to the grain, Fracture 強度算定法, 木質ボルト, 䋊維方向荷重, 破壞

\section{1. はじめに}

集成材構造等の非住宅木質構造では、接合部の性能で構造物の構 造性能が決まることが多い。しかし、その接合部の強度を説明するメカニ ズムに不明な点が多い。2006 年度の本学会の木質構造設計規準 ${ }^{1)}$ の改 正で、降伏耐力と終局耐力が示されたが、繊維方向加力を受けるボル卜 接合の終局耐力は、塑性理論をベースとしたヨーロッパ型降伏理論 $(\mathrm{EYT} \text { 式 })^{1,2)}$ に基づくものであり、現実の破壊形態である木部の割裂がパ ラメータとして含まれておらず、現状の木質接合研究の観点からは、終局 設計体系を促すための勇断を伴った改訂であったとも言えよう。したがっ て、検討不十分と考えられる割裂・せん断破壊の問題を早急に詰めるの が、木質研究者の急務と考える。最近の割裂に関連した研究として、桑 村らの杉山の初等力学モデルを再検討した方法 ${ }^{3)}$ 、神戸らの鋼構造で 一般的な破壊力学的な手法を木質材料に応用した方法 ${ }^{4), 5}$ 夯報告され ている。前者のアプローチは、割裂の原因となる集中応力を初等理論を 用いてモデル化したものであり、理屈上、割裂が生じる荷重を推定するの に適している。少しでも割れが入れば即部材の耐力が失われるような欠 点を持つ木質部材や長期荷重等を受ける欠点を持つ木質部材の強度 算定法誘導に大変有効と考えられる。しかし、繊維方向負荷を受けるボ ル卜接合などの場合、割れが生じても耐力低下が殆じ起こらない場合もあ ることから、集中応力だけではなく、破壊力学的なアプローチも必要と考 えられる。後者のアプローチは、破壊力学の学問的基礎知見の備蓄に 有効である。しかし、FEM を前提としており、より簡易な方法が望ましいと 考える。我々のアプローチは、集中応力だけではなく、破壊力学的なア プローチを併用し、初等理論で簡易モデル化を行い、それに基づく強度 算定式を誘導する点が特徴である。
本論文では割裂破壊を引き起こす要因であるボルトのくさび作用や縁 端距離不足の影響についてモデル化を行い、単体木質ボル下接合の最 大強度算定法を提案する。なお、木質ボル卜接合部の配置の規制 (縁距 離や端距離、ボル卜間隔等) が厳しいために、要求性能を満たすために 規制以下の配置で新しい接合部を開発する場合が多く、それらの知見も 必要との立場から、設計規準以下の端距離・縁距離も含めて扱う。

木質ボル卜接合部の繊維方向加力の実験的研究は国内外を含めると 数えきれないほど報告されているが、理論を提案した研究は数少ない。 特に、破壊について扱ったものは、 Jorrisen ${ }^{6}$ や Heine ${ }^{7)}$ のオリジナルプロ グラムによる数值解析、FEM と圧縮破壞クライテリアを用いた Masuda ${ }^{8)}$ や Tan $5^{9)}$ の解析的研究が挙げられるが、手計算可能で比較的簡易な 理論化による報告はほとんどなく、広く認められた理論はない。

本論文では、 1 本の木質ボル卜接合の最大強度の 1 つの算定法を提 案し、実験により妥当性を確認する。第 2 章から第 7 章までで、 1 本の木 質ボル卜接合の最大強度の 1 つの算定法を誘導する。第 8 章では、提案 算定法を用いた計算值と実験結果を用いて提案算定法の妥当性を検証 する。

\section{2. 木質ボル卜接合単体の破壊強度算定式の基本方針}

本章では後で説明する検証実験で観察された破壊形態を基に簡易モ デル化を行い、繊維方向加力を受けるボル卜接合単体の強度算定式を 導出する。

\section{1 想定した破壊形態}

図 1 に検証実験で観察された 4 つの典型的な破壊形態を示す。図 1 (a)に示す破壊形態は、 $1 d$ や $2.5 d$ などと ( $d$ :ボルトの直径) 端距離が非 常に小さい場合に観察された。本論文では、この破壊形態をブロックせ

\footnotetext{
* 工学院大学地震防災・環境研究センター ポストドクター・農博

** 東京工業大学建築物理研究センター 准教授·工博

*** 東京工業大学建築物理研究センター 教授. 工博

$* * *$ 工学院大学建築学科 教授.工博

Postdoctoral Fellow, Earthquake and Environment Research Center, Kogakuin University

Assoc. Prof., S.E.R.C., Tokyo Institute of Technology

Prof., S.E.R.C., Tokyo Institute of Technology

Prof., Dept. of Architecture, Faculty of Engineering, Kogakuin University
} 
几断破壊と呼ぶ。図 1(b)に示寸破壊形態は、ブロックせん断破壞と同様 に端距離 $1 d$ や $2.5 d$ などの場合に観察された破壊形態である。本論文で は、この破壊形態を端あき部の曲げ破壊と呼ぶ。図 1 ( c) に示寸破壊形 態は、めり込み降伏が起こる前に割裂破壊が起こる場合の加力部からの 破壊である。この破壞形態を支圧応力による割裂破壊と呼ぶ。図 1 (d) に 示寸破壊形態は、めり込みが起こった後に、割裂破壊が起こる場合であ る。本論文では、この破壊形態を押し広げによる割裂破壊と呼ぶ。

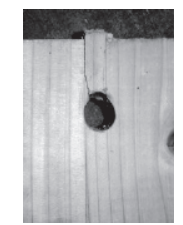

(a)

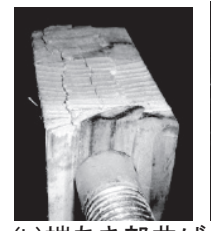

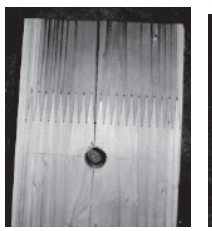
よる割裂
支压応力に

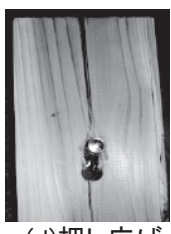

(d)押し広げ による割裂
図 1 実験で観察された典型的な破壊形態

なお、ブロックせん断破壊と端あき部の曲げ破壊は、割れが生じた時 点で耐力がほぼゼロに低下する破壞形態に対し、支圧応力による割裂 破壊及び押し広げによる割裂破壊は、小さな割れが生じても耐力低下は 小さく(試験体によっては耐力低下がない場合もあった) 割れが大きく進 展すると、急激な耐力低下が生じボル下接合の破壊に至った。

\section{2 モデル化の基本方針}

まず、破壊の定義について述べる。ブロックせん断破壊と端あき部の 曲げ破壊は、存在応力が材料強度に達した時点を破壊と定義した。また、 支圧応力による割裂破壊、押し広げによる割裂破壞は、破壊エネルギー に基づく非線形破壊力学を用いて破壞を定義した。

非線形破壊力学は、van der Put ${ }^{10)}$ 、Peterson ${ }^{11)}$ 、 Jensen ${ }^{12)}$ 、 Gustafsson ${ }^{13)}$ が木材の破壞モデルに採用したクライテリアに準じた。すな わち、破壊クライテリアは、ポテンシャルエネルギーの減少分 (=外部仕 事の減少分)がある基準(破壞エネルギー)に達したとき、破壞と定義した。 数式では式(1)となる。

$$
G_{c}=\frac{\Delta W}{\Delta \beta}=\frac{d W}{d \beta} \quad \cdots \quad(1)
$$

ただし、 $\Delta W=P \cdot \delta_{1}-P \cdot \delta_{2}=P \cdot\left(\delta_{1}-\delta_{2}\right) 、 P$ : 加力点の荷重、 $\delta_{1}$ : 割れが 進展する前の加力点での変位、 $\delta_{2}$ : 割れが $\Delta \beta$ 進展した後の加力点での 変位、 $\Delta \beta$ :クラック長さ

後で述べる非線形破壞力学を用いたモデル化では、数式誘導が若干 複雑になるため、本論文での非線形破壊力学モデル化の大きな流れ (具 体的作業)をここで以下に述べておく。

(1) 接合部に作用寸る力 $P$ と、繊維直角方向の分力や二次応力等を等 価な繊維直角方向の荷重 $P_{t}$ (割裂き力) との関係をモデル化する。

(2) 割裂き力が作用した場合の木材の割裂破壊をモデル化する。

1) 割れが入っていない初期状態及び割れが $\Delta \beta$ 進展した状態を想定 する。

2 ) 初期状態のモデル化を行い、 $P_{t}$ が働く位置での変形を算出する。

3 ) 初期状態から割れが $\Delta \beta$ 進展した状態のモデル化を行い、 $P_{t}$ が働く 位置での変形を算出する。

4) 初期状態、及び、割れが $\Delta \beta$ 進展した状態のそれぞれについて、割 裂き力 $P_{t}$ がな寸仕事を求める

5)「(仕事) $=$ (エネルギー)」の関係を用いて、「(割れが $\Delta \beta$ 進展した 場合のポテンシャルエネルギーの減少分 $)=($ 初期状態で割裂き
力 $P_{t}$ がなす仕事 $)$ - (割れが $\Delta \beta$ 進展した状態で割裂き力 $P_{t}$ が な寸仕事)」と考える。

6)破壊は「(ポテンシャルエネルギーの減少分 $)=($ 破壊エネルギー $) 」$

の関係より、割裂き力 $P_{t}$ の限界值を求める。

(3) 接合部に作用寸る力 $P$ と割裂き力 $P_{t}$ の関係、及び、割裂き力 $P_{t}$ の限 界值から接合部の強度算定式を導出寸る。

また本論文では、力学を用いて手計算可能な算定式を導くことを目的 としている。このため、式が複雑になる部分は仮定を設定し、簡易・単純 化した。論文全体を通して、ボルト及びボルト孔は円形であるが、簡易化 のために、ボルト孔を正方形として扱う。このとき、等価な正方形の孔の辺 長はボルトの直径と同じ $d \mathrm{~mm}$ とした。

\section{3. ブロックせん断破壊モデル}

\section{1 破壊要因の解釈と学モデル化の方針}

破壊の発生要因は、せん断面が長く応力集中が起こったためではなく、 端あき部が短いために木部に作用したせん断応力度が強度に達したた めと考えた。そこで、せん断応力分布は一様として扱う。

\section{2 ブロックせん断破壊の強度算定式の導出}

図 2 にブロックせん断破壊のモデルを示す。せん断応力分布はせん断 面において一様と仮定し、せん断応力度がせん断強度に達すれば破壊 とすると、ブロックせん断で壊れる場合の強度算定式を式(2)として導出 した。

$$
P=2 \cdot e_{h} \cdot t \cdot \tau \quad \cdots(2)
$$

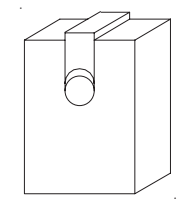

(a) 破壊の想定
図 2 ブロックせん断破壊の想定とモデル化

\section{4 端あき部の曲げ破壊モデル}

\section{1 破壊要因の解釈と力学モデル化の方針}

この破壞は図 1(b) にみられる割れのうち、はじめに真ん中の割 れが生じ、その後に両サイドの割れが生じる場合が多かった。しか し、割れは、まず、左右のどちらか一方に生じ、その後、真ん中の 割れが生じる場合も観察された。

端あき部の曲げ破壊の応力想定を図 $3(a)$ に示す。端あき部の応力 伝達機構を図 3 (b) に示寸ように、中央集中荷重を受ける両端固定の 等価なはりでモデル化する。集中荷重を与えた位置は図 3 (c) に示す ように等価はりの中央とした。

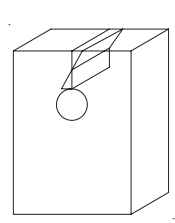

（a）破壊を引き起こす応力の想定

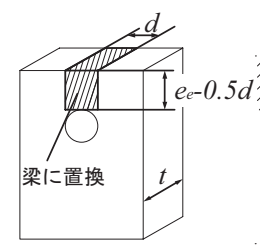

(b) モデル

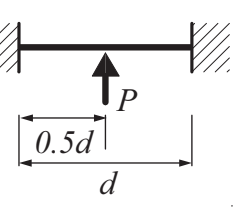

(c)力学モデル
図 3 端あき部の曲げ破壊の想定とモデル化

\section{2 端あき部の曲げ破壞での強度算定式の導出}

梁の中央及び両側の固定端で最大の曲げモーメント $M$ になり、 それらの值は梁の初等理論を用いて式(3)で表せる。 


$$
M=\frac{P d}{8} \quad \cdots(3)
$$

平面保持を仮定すると、危険断面での曲げ応力度は式(4)で表せる。 なお、最大の曲げモーメント $M$ と等価な断面係数 $Z$ 、このとき有 効な梁の断面形状は図 3(b)の斜線部として扱った。

$$
\sigma=\frac{M}{Z} \quad \cdots(4)
$$

式(3)と式(4)を連立させて $P$ について整理すると、曲げモーメン 卜による引張応力が作用する危険断面で横引張破壊するとしたとき のボルトのせん断耐力算定式を式(5)として導出した。

$$
P=\frac{4 \cdot t \cdot e_{h}^{2} \cdot \sigma_{t}}{3 \cdot d} \quad \cdots(5)
$$

\section{5. 支圧応力に起因する割裂破壊}

\section{1 破壊要因の解釈}

この破壊形態は、ボルトが円形であるためにその分力としてボル トと木材が接している部分に局部的に生じる繊維直角方向成分をも つ二次応力を起因として加力部から割裂が生じた。割裂破壊の発生 要因は、引き裂く方向の分力による破壞と考えた。

\section{2 接合部に作用するカと割裂きカの関係のモデル化の方針}

つぎに、繊維直角方向に働く割裂き力 $P_{t}$ について考える。割裂き力 $P_{t}$ の要素を 2 考えた。そして、それらの合力を割裂き力 $P_{t}$ と仮定した。

1 つ目は、図 4(b)に示すように、ボルトが円形であるためにボルトと木 材が接している支圧部が平面的ではなく半円形であるために、局部的に 生じる繊維直角方向成分をもつ分力が二次応力として働く分力である。 この作用をくさび作用による割裂き力と呼ぶ。2つ目は、図 4 (c) に示すよ うなポアソン効果による引き裂き力を考える。

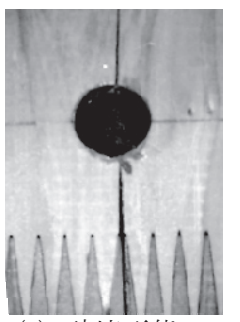

(a) 破壊形態

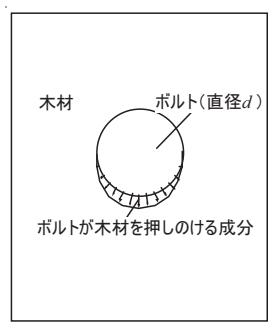

(b)くさび効果
図 4 考慮する割裂き力

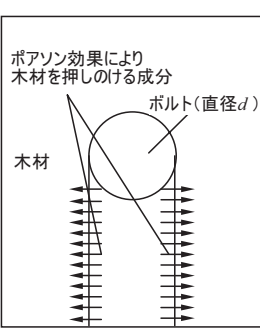

(c)ポアソン効果

\section{3 くさび作用のモデル化の方針}

くさび作用 (くさび効果)については、機械設計や工業力学において、 広く理論化されている ${ }^{14)}$ 。しかし、䋊維方向と繊維直角方向のヤング係 数及び強度が大きく異なる木材・木質材料の場合には、異方性の影響を 考慮する必要があると考える。Kuiper や Jorissen は、工業力学でのくさび 理論を応用して、木質ボル卜接合部のくさび作用をモデル化しているが、 異方性は考慮していない。

本論文では、異方性を考慮した木質ボル卜接合部のくさび効果を新た に提案する。最初に、摩擦なし・ボル卜直径と先孔径が同一とした場合に ついてモデル化を行う。つぎに、摩擦の影響を考慮したモデル化を行う。 最後に、ボル卜直径と先孔径が異なる場合について検討する。

\section{3.1 木材の異方性を考慮したくさび作用のモデル化}

円形ボル卜の断面の中心を基準に、任意の角度 $\theta$ におけるボルトと木 材の接触点では、ボルトが外周円の放射方向に木材を押しのけるように 作用すると仮定する(図 5 参照)。そうすると、 $\theta$ が 0 の点の変位を $\delta$ とす
ると、任意の角度 $\theta$ における放射方向にボルトが木材を押しのける変 位量は、 $\delta \cos \theta$ で表現できる。この変位量を繊維方向と繊維直角方向 に分解すると図 6(a)に示すようになる。

木材は直交異方性であるため、それぞれの方向の変位量に対する木 材の支圧抵抗力の比は異なるはずである。そこで、 $k_{a 0}$ と $k_{a 90}$ をそれぞれ 木材の繊維方向と繊維直角方向の変形しにくさを表すバネ(応力度 $\div$ め り込み量)とし、それぞれの方向の分力を示すと図 6(b)のようになる。

ボル卜直径と先孔径が同一と考えているので、繊維方向の分力成分を$\pi / 2$ から $\pi / 2$ まで積分すると、繊維方向の分力の総和 $P$ が式(6)として求 まる。なお、繊維方向の分力 $P$ はボル卜に作用寸る力と考えられる。

$$
P=\int_{\frac{\pi}{2}}^{\frac{\pi}{2}} k_{\alpha 0} \cos ^{2} \theta d \theta=2 k_{\alpha 0} \int_{0}^{\frac{\pi}{2}} \cos ^{2} \theta d \theta=\frac{\pi \alpha}{2} \quad \cdots \quad(6)
$$

同様にして、繊維直角方向の分力成分を $-\pi / 2$ から $\pi / 2$ まで積分寸 ると、繊維直角方向の分力 $P_{t}$ が式 (7) として求まる。なお、繊維 直角方向の分力の総和 $P_{t}$ はボルトが木材を引き裂く割裂き力と考え られる。

$$
P_{t}=\int_{-\frac{\pi}{2}}^{\frac{\pi}{2}} k_{\alpha 90} \cos \theta \sin \theta d \theta=2 k_{\alpha 90} \int_{0}^{\frac{\pi}{2}} \cos \theta \sin \theta d \theta=k_{\alpha 90}
$$

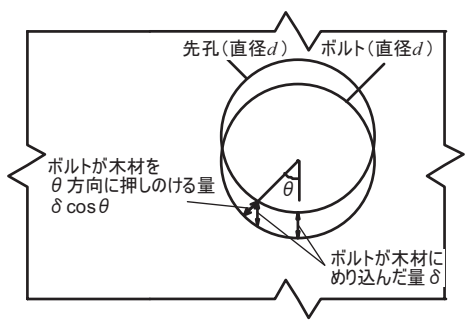

図 5 任意の角度 $\theta$ でのボルトが木材を押しのけるモデル

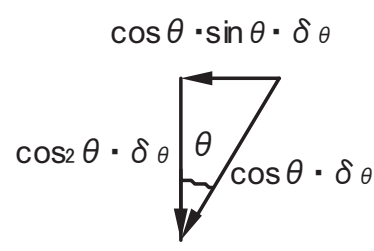

(a) 変形要素

$$
\text { 図 } 6 \text { 任意の角度 } \theta \text { の各要素成分 }
$$

式(6)と式(7)を連立することにより、割裂き力 $P_{t}$ とボルトに作用 する力 $P$ との関係を式 $(8)$ で表現できる。

$$
P_{t}=\frac{2 k_{\alpha 90}}{\pi k_{\alpha 0}} P \quad \cdots(8)
$$

つぎに、 $k_{\alpha 0}$ と $k_{\alpha, 90}$ の関係を導く。 $k_{\alpha 0}$ と $k_{\alpha 90}$ との関係を考える上で参考と なる物理量は、木材の弾性係数、又は、丸鋼を押しつけたときの面圧係 数(支圧係数)の異方性がある。しかし、AIJ 木質構造設計規準において、 繊維方向に対する繊維直角方向の值は、前者は $1 / 25$ 、後者は $1 / 3.4$ が提 案されている。前者と後者の比率が大きく異なるため、力学 (数学) 的に $k_{\alpha 0}$ と $k_{\alpha 90}$ の関係を以下に検討する。

ここでは、丸鋼の面圧実験について考える。図 7 に示すように、緎維方 向、及び、繊維直角方向について上の誘導と同様にして、面圧力、及び、 割裂き力を導く。繊維方向の面圧力 $A$ は、式(9)で表現できる。

$$
A=\int_{-\frac{\pi}{2}}^{\frac{\pi}{2}} k_{\alpha 0} \delta \cos ^{2} \theta d \theta=2 k_{\alpha 0} \delta \int_{0}^{\frac{\pi}{2}} \cos ^{2} \theta d \theta \quad \cdots \text { (9) }
$$

繊維直角方向の面圧力 $B$ は、式(10)で表現できる。 


$$
B=\int_{\frac{\pi}{2}}^{\frac{\pi}{2}} k_{\alpha 90} \delta \cos ^{2} \theta d \theta=2 k_{\alpha 90} \delta \int_{0}^{\frac{\pi}{2}} \cos ^{2} \theta d \theta \quad \cdots \text { (10) }
$$

式(9)と式(10)より、 $A$ と $B$ の関係式は以下のように誘導できる。

$$
\frac{B}{A}=\frac{2 k_{\alpha 90} \delta \int_{0}^{\frac{\pi}{2}} \cos ^{2} \theta d \theta}{2 k_{\alpha 0} \delta \int_{0}^{\frac{\pi}{2}} \cos ^{2} \theta d \theta}=\frac{k_{\alpha 90}}{k_{\alpha 0}} \quad \ldots \text { (11) }
$$

$A$ 、及び、 $B$ はある任意変位量 $\delta$ での荷重とすると、AIJ 基準での丸鋼 の面圧係数の関係式を用いることができる。

$$
\frac{B}{A}=\frac{k_{\alpha 90}}{k_{\alpha 0}}=\frac{1}{3.4}
$$

以上から、ボルトに作用する力 $P$ と割裂き力 $P_{t}$ の関係は、式(13) とし て誘導できる。

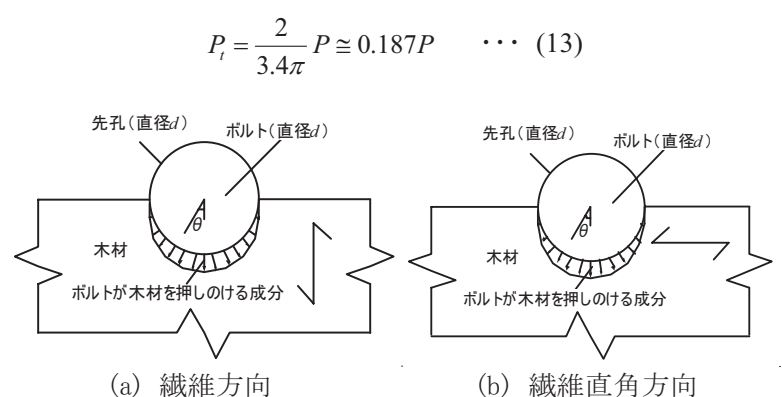

図 7 面圧実験での考え方

\subsection{2 ボルトと木材の接触部での摩擦力を考慮したくさび作用のモデル化}

ここでは、ボルトと木材の接触部での摩擦力の影響について考える。 任意角度 $\theta$ におけるボルトと木材の微小の接触点は、角度 $\theta$ をもつくび と同じ機構であると考えられる。そこで、摩擦についての扱いは、工業力 学で確立されているくさび作用理論 ${ }^{14)}$ の方法を用いる。つまり「力のベク トルが摩擦角 $\rho$ だけかたむく」を用いた。摩擦角については、村瀬 ${ }^{15)}$ 、林 ら ${ }^{16)}$ の鋼材と木材の摩擦係数を参考に、摩擦係数を 0.3 とし、そのときの 摩擦角を $18^{\circ}(\fallingdotseq \pi / 10)$ とした。

図 8 に木材の異方性と摩擦を考慮したくさびモデル及び FEM 解析で 算出した支圧部応力の比較を示す。FEM 解析の詳細は、Appendix を参 照。図 8 から、くさびモデルで求めた応力分布と FEM の解析で求めた応 力分布は一致しているとは言えないが、大きな傾向としてはおおむね抑 えていると判断した。くさびモデルの更なる改良は必要ではあるが、異方 性、及び、摩擦の考慮が必要であることが確認できた。

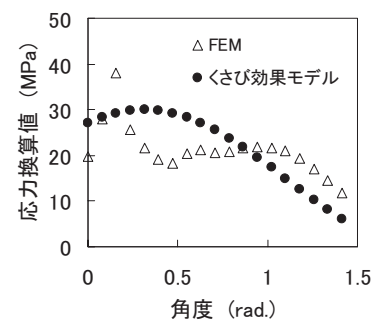

(a) 繊維方向応力

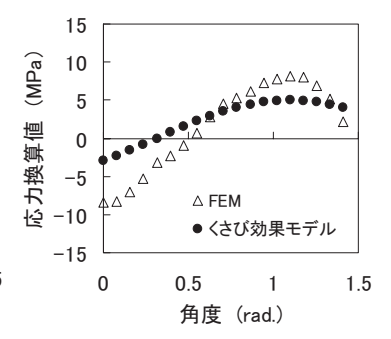

(b) 繊維直角方向応力
図 8 くさびモデルと FEM 解析の支圧部応力の比較

式 (6)、（7）と同様な考え方で合力を求めると、ボル卜接合部に働 く力 $P$ と割裂き力 $P_{t}$ は、それぞれ式(14)、(15)で表現できる。式 (14) と 式(15)を連立することで、ボル卜接合部に働く力 $P$ と割裂き力 $P_{t}$ の関係は 式(16)として求められる。

$$
P=2 k_{\alpha 0} \int_{0}^{\frac{\pi}{2}} \cos ^{2}\left(\theta-\frac{\pi}{10}\right) d \theta
$$

$$
\begin{array}{r}
P_{t}=2 k_{\alpha 90} \frac{\int_{\frac{\pi}{1}}^{\frac{\pi}{2}} \cos \left(\theta-\frac{\pi}{10}\right) \sin \left(\theta-\frac{\pi}{10}\right) d \theta}{P_{t}} \cong 0.172 P \quad \ldots(16)
\end{array}
$$

\section{3. 3 くさび作用におけるボルト直径と先孔径の違いの検討}

初期状態として A 点のみが接触している状態を想定する。初期状態で ボルトの中心から角度 $\theta$ において、ボルト円上の $\mathrm{A}$ 点と先孔の円上の A' 点と $\mathrm{y}$ 軸方向の距離 $\delta_{\theta}{ }_{\theta}$ を求める。まず、図 $9(\mathrm{~b})$ に示すボル卜と先孔それ ぞれの中心が一致している場合を考える。ボル卜は円であるため、中心を 原点、半径 $r$ (先孔は $r^{\prime}$ ) とすると、ボル卜上の点は、下式で表される。

$$
x=r \sin \theta, \quad y=r \cos \theta \quad \cdots(17)
$$

また、先孔も円であるため、中心を原点、半径 $r$ 'とすると、先孔 上の点は、以下の式で表される。

$$
x^{2}+y^{2}=r^{\prime 2} \quad \cdots(18)
$$

先孔の円上 $\mathrm{A}^{\prime}$ 点の $y$ 座標值は、式(17) 及び式(18) を連立すると、

$$
y=\sqrt{r^{\prime 2}-d^{2} \sin ^{2} \theta} \quad \cdots(19)
$$

したがって、A 点 $\mathrm{A}^{\prime}$ 点と $\mathrm{y}$ 軸方向の距離 $\delta^{\prime}{ }_{\theta}$ は下式として導ける。

$$
\delta_{\theta}^{\prime}=r \cos \theta-\sqrt{r^{\prime 2}-d^{2} \sin ^{2} \theta}-\frac{\left(d^{\prime}-d\right)}{2} \quad \cdots \quad(20)
$$

ボルトと先孔との隙間で、割裂き力に影響するのは、接触角である。ボ ルトと先孔の隙間が大きいと、式 (6)や式(7)での積分区間が小さくなり、 割裂き力が結果的に小さくなる。すなわち、安全側の評価のためには、ボ ル下接合の降伏変位を大きく見積もった場合のとりうる值を求め、その降 伏変位と図 10 のボルト径と先孔系との隙間の関係から、積分区間を決定 することができる。

図 10 に式(20)を用いてボルト径と先孔系の隙間を算出した結果を示 す。また、図 11 に実験結果を降伏変位と終局変位の関係にまとめ直した グラフを示す。図 11 から、ボルト接合の降伏変位はばらついているが、大 きく見積もる場合は、少なくとも $2 \mathrm{~mm}$ から $3 \mathrm{~mm}$ 程度は想定しないといけな いことが分かる。なお、終局変位が $15 \mathrm{~mm}$ 以上と大変大きな条件では、ボ ルトのロープ効果が発生して、国内の木質構造の一般的な評価法 ${ }^{17)}$ で 評価すると、降伏変位が大きく出たものと考えられる。そのため、終局変 位が $15 \mathrm{~mm}$ 以下の条件のもので考え、降伏変位を $3 \mathrm{~mm}$ と考えた。降伏 変位を $3 \mathrm{~mm}$ とした場合、ボル下径 16 と先孔系が $17 \mathrm{~mm}$ 、又は、 $18 \mathrm{~mm}$ の 場合でも、角度はおおむね $\pi / 2$ 付近となっている。そこで、本研究では、 ボル卜径と先孔径に差があっても、積分区間は- $\pi / 2$ から $\pi / 2$ とした。
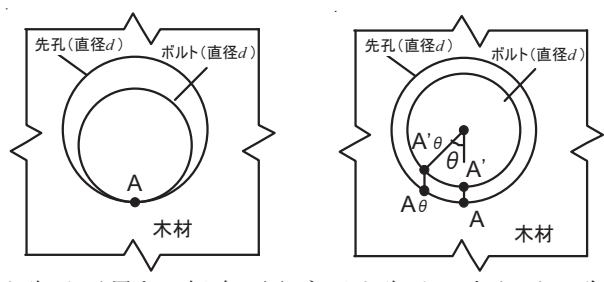

(a)ボルトと先孔が異なる想定（b)ボルトと先孔の中心が一致する場合 図 9 ボルト径と先孔系が異なる場合のモデル

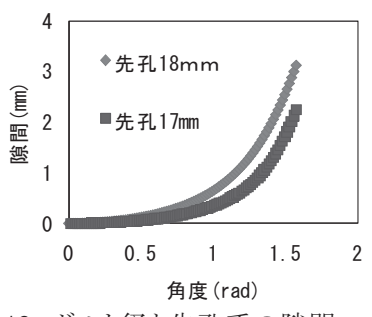

図 10 ボル卜径と先孔系の隙間 (ボルト直径 16mm)

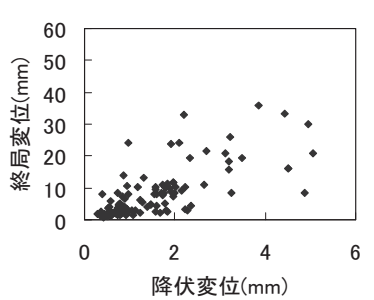

図 11 降伏変位と終局変位の関係 (実験結果) 


\section{4 ポアソン効果のモデル化}

ポアソン効果は、ある方向に軸方向ひずみを与えると、その直角方向 に異符号のひずみを生じる現象である。材の一部に外力として軸応力が 作用し、かつ、ひずみが発生する部分の両サイドに横ひずみ方向の変形 拘束がある場合には、局所的に 2 次応力としての引張応力が発生する場 合が考えられる。具体的には、モデル化を通して解説する。

モデル化の方針を以下に示す。図 12(b)に示すように、木材を(A)〜 $($ まま での 6 個のブロックに分けて考える。そして、ボル卜接合部に作用している 応力を、図 $12(a)$ に示寸ように、応力状態 1 と応力状態 2 に分離できると 仮定寸る。応力状態 1 では、ポアソン効果は部材全体を押し縮める方向 に働く。他方、応力状態 2 では、端あき部(®、(Bと@)のポアソン効果は 端あき部を押し開く方向に働く。本来なら、応力状態 1 及び応力状態 2 それぞれについてモデル化して、それらをたしあわすべきであるが、本モ デルでは応力状態 2 のみを考慮した。なぜなら(1)一般的なボル下接合の 条件では、明らかに応力状態 2 によるポアソン効果による割裂き力が支 配的になる。(2)応力状態 2 のみを考慮することは安全側の判断となる。 (3)応力状態 1 及び 2 を考慮すると式が煩雑になる。

応力状態 2 では、端あき部 (@)+B + (C) ) は、ボル卜部の局部圧縮が図 13 (a)のように応力が拡散し、図 4(c) に示すようにポアソン効果により横 ひずみが生じる。応力拡散する角度が一定であると仮定し、かつ、（）（、、 及び、(Aと(Dでの適合条件を $\mathrm{F} 2$ 及び $\mathrm{A} 2$ での連続条件を満たすとモデ ル化すると、ポアソン効果による横ひずみの大きさは、図 13 (b) と図 13 (c) では同じものになる。本来なら、E2 と B2 において適合条件を考えるべき とも考えられるが、F2 及び A2 で考えた場合の方が安全側になり、且つ、 簡易になるため E2 と B 2 で連続条件を考えた。つまり、以後扱いとしては、 図 13 (c) における®での横ひずみによる割裂き力を求めることになる。

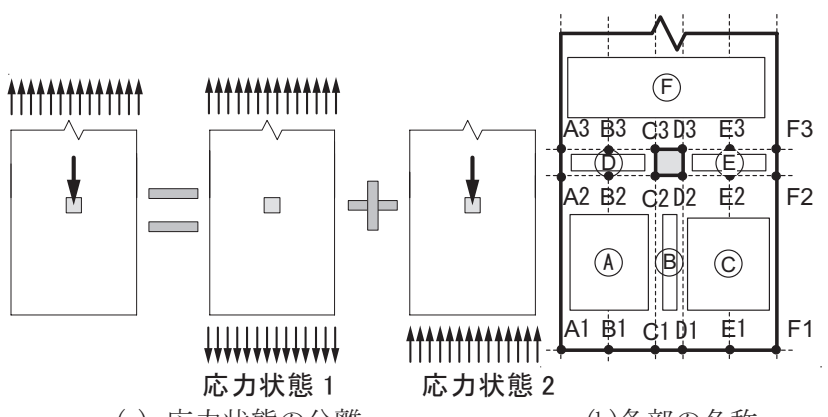

(a) 応力状態の分離

図 12 破壊形態とモデル化

土質力学ではポアソン効果を考えることがあるが、木質構造では、今ま では、ポアソン効果の影響を考えることが殆どなく、なぜ、®でのポアソン 効果が割裂き力に関係するかをイメージするのに若干の困難を伴う場合 も考えられるため、少し解説を入れる。でのポアソン効果による 2 次応

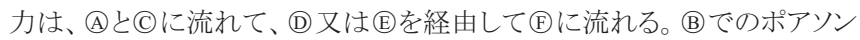
効果により、(D及び®は、それぞれ開く方向に応力が作用する。その力 の大きさは、®でのポアソン効果により発生する力と同じと考えられる。す なわち、(Bでのポアソン効果による二次応力を荷重と考えずに、(D及び (巨でそれぞれ開く方向に等価な力を荷重として与えた場合と応力状態は 同じである。そうすると、ポアソン効果により割裂き力が発生し、その大き さは、ポアソン効果により発生する力と同じである事が容易に分からう。 Bの部分での公称横ひずみ $\varepsilon_{\perp}$ は以下のように表される。

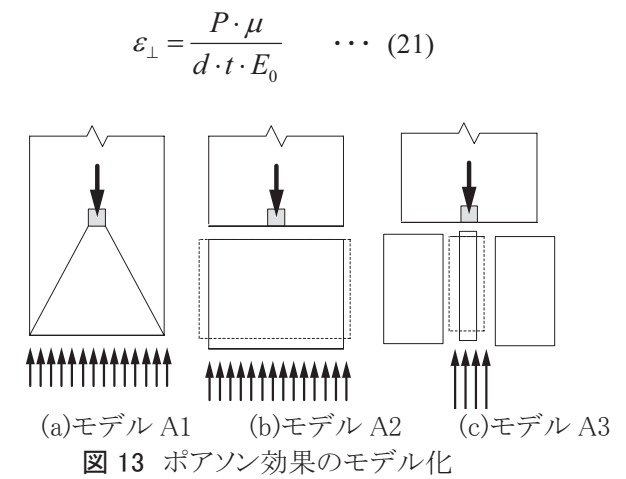

横ひずみに繊維直角方向のヤング係数 $E_{90}$ を乗じて、長さ方向 (D2 -D1 又は $\mathrm{C} 2-\mathrm{C} 1$ 方向)について積分するとポアソン効果による割 裂き力 $P_{t}$ は左右に働き、大きさは以下の式で表される。

$$
P_{t}=\varepsilon_{\perp} \cdot E_{90} \cdot t \cdot e_{h}=\frac{\mu \cdot e_{h} E_{90}}{E_{0} \cdot d} P \quad \cdots(22)
$$

ここで、木質構造設計規準の $E_{90}$ と $E_{0}$ の関係を用いると以下のよ うなる。

$$
P_{t}=\frac{\mu}{25} \times \frac{e_{h}}{d} P \quad \cdots(23)
$$

ここで、 $e_{h} / d$ にいて考える。式(23)では、 $e_{h} / d$ は実際の端距

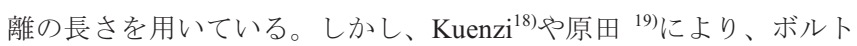
の面圧性能は部分圧縮であるため、実際の端距離の長さではなく、 有効弾性床長さ (面圧凹及係数) を用いることが提案されている。本 論文でも、この考えを用いて、 $e_{h} / d$ を有効弾性床長さに置き換える。 有効弾性床長さは AIJ 基準 ${ }^{1)}$ の解説では、以下のような式が示され ている。

$$
\alpha=3.16+10.9 d \quad \cdots(24)
$$

直径 $16 \mathrm{~mm}$ の場合は、有効弾性床長さは $206 \mathrm{~mm}(12.9 d)$ となる。 図 14 にボルト直径と式(24)で計算した有効弾性床深さを示す。直径 が $10 \mathrm{~mm}$ 以上では、それほど変化する值ではないことが分かる。そ こで本論文では、有効弾性床長さを $13 d$ として扱う。また、木材工 業ハンドブック ${ }^{20)}$ を参考に、 $\mu_{\mathrm{LT}}$ と $\mu_{\mathrm{LR}}$ を平均した值である 0.49 を 用いた。つまり、式(23) は以下のようになる。

$$
P_{t}=0.255 P \quad \cdots(25)
$$

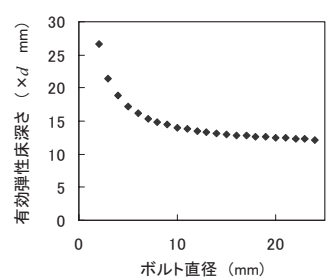

図 14 有効弾性床長さの計算值

\section{5 割裂きカが作用した場合の木材の割裂破壊モデル}

割れが進展する前の加力部の変形考える。図 15 に示す幾何学的関 係から、割れが進展する前の加力部の変位は式(26)で表せられる。なお、 等価な両端固定の梁の曲げ変形とせん断変形を考慮した。すなわち、右 辺の第一項は曲げによる変位を、右辺の第二項はせん断による変位を 表している。なお、せん断変形が曲げ変形より支配的になる特殊なケー スであるが、初等理論でせん断変形を求めるには限界がある。本論文は、 簡易モデルによる定式化を目的としていることから、一般的な簡易な初等 理論、すなわち、オイラー・ベルヌーイ梁で応力分布を求め、エネルギー 
法でせん断変形を求めた。

$$
\delta_{1}=\frac{P_{t} \cdot d^{2}}{2 \cdot E \cdot t \cdot\left(e_{e}-0.5 \cdot d\right)^{3}} \times \frac{d}{16}+\frac{\kappa \cdot P_{t} \cdot d}{5.09 G \cdot t \cdot e_{e}} \quad \cdots(26)
$$

ただし、 $d:$ ボルトの直径、 $I$ : 等価梁置換した場合の断面二次モ一 メント、 $E$ : ヤング係数、 $e_{e}$ : 縁距離、 $t$ : 材幅、

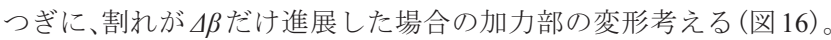
このクライテリアは、ボルトが過度にめり込まない場合を想定して いる。そのため、ボルトの座標位置は初期状態から移動しないと仮 定し、集中荷重を与える座標位置は図 16 (c) に示すように初期状態 と同じ位置とした。図 16 の中に示寸幾何学的関係から、割れが $\Delta \beta$ だけ進展した場合の加力部の変形は式(27)で表せられる。

$\delta_{2}=\frac{P_{t} \cdot d^{2}}{2 \cdot E \cdot t \cdot\left(e_{e}-0.5 \cdot d\right)^{3}} \times \frac{9 \cdot\left(\frac{d}{4}+\Delta \beta\right)^{3}}{\left(\frac{3 \cdot d}{2}+\Delta \beta\right)^{2}}+\frac{\kappa \cdot P_{t} \cdot d}{5.09 G \cdot t \cdot e_{e}}+\frac{\kappa \cdot P_{t} \cdot \Delta \beta}{1.40 G \cdot t \cdot e_{e}} \ldots$

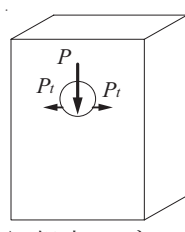

(a) 想定モデル

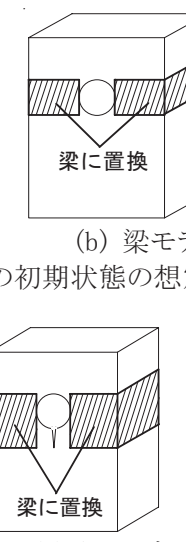

(b) 梁モデル

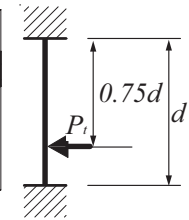

(c)力学モデル
図 15 割れが入る前の初期状態の想定モデルと力学モデル

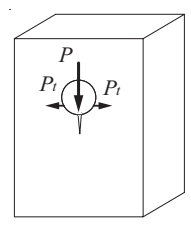

(a) 想定モデル

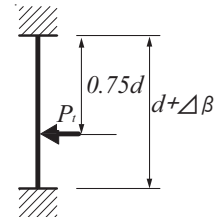

(c)力学モデル
図 16 割れが $\Delta \beta$ 進展した場合の想定モデルと力学モデル

式(1)、式(26)、式(27) から、割裂き力 $P_{t}$ が抵抗しうる強度を式 （28）として導出できる。ただし、両サイドに引き裂く事を考慮して 求めた。

$$
P_{t}=\sqrt{\frac{2 G_{c} t}{\frac{2 d^{2}}{2 \cdot E \cdot t \cdot\left(e_{e}-0.5 \cdot d\right)^{3}} \times \frac{(d+4 \Delta \beta)^{3}(4 d+\Delta \beta)}{2(3 d+2 \Delta \beta)^{2}}+\frac{2 \kappa}{1.40 G \cdot t \cdot e_{e}}}}
$$

現実的な寸法を考えると、曲げ変形はせん断変形と比べて無視で きる程度に小さいと考えられ、簡易化のため曲げ変形成分を省略す

$$
P_{t}=t \sqrt{\frac{1.40 G \cdot e_{e} G_{c}}{1.2}}=t \sqrt{1.16 G \cdot e_{e} G_{c}} \quad \cdots \quad(29)
$$

\section{6 支圧応力に起因する割裂破壊の強度算定式の導出}

ボルト接合部に作用する力 $P$ と割裂き力 $P_{t}$ の関係から、支圧応力 に起因する割裂破壊の強度算定式は式 (30) として導出できる。

$$
P=\frac{t \sqrt{1.16 G \cdot e_{e} G_{c}}}{0.341} \quad \cdots(30)
$$

\section{6. 押し広げによる割裂破壊モデル}

\section{1 破壊要因の解釈}

割裂破壊の発生要因は、ボル卜接合部の変形に伴いボルトが木材に めり込み、木材を押し広げるために割れが生じる。この破壞形態は、ボル 卜接合部が降伏変位を越えて十分に変形が進んだ状態を想定している。
支圧応力に起因する割裂破壊とこの押し広げによる割裂破壊の違いは、 接合部が降伏しておらずめり込みがほとんど生じていない場合の割裂破 壞と接合部が降伏した後のめり込みが十分起こった後の割裂破壊との違 いを想定している。
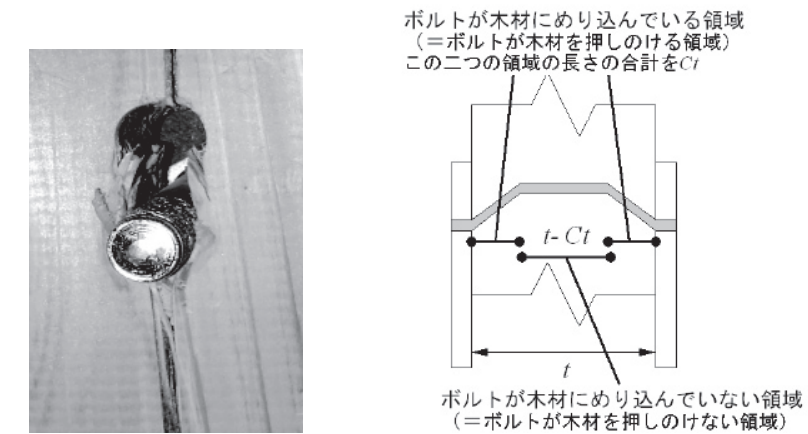

図 17 押し広げによる割裂破壊写真

\section{2 接合部に作用するカと割裂きカの関係のモデル化}

本モデルでは、ボルトが木材を押しのける体積を用いて、接合部降伏 後の割裂き力を近似的に求める。なお、ボル卜が木材を押しのけるす心゙ ての体積は、繊維直角方向に押しのけられると考える。ボルトが木材を押 しのける体積は、ボルト材軸方向とボルトの断面方向の性質が影響する。

\section{2.1 ボルトが木材を押し広げる面積のボルト材軸方向について}

ボルトが木材にめり込む部分のみがボルトが木材を繊維直角方向に 押しのける部分と考えられる。ボル下接合は、径長比などにより、ボルトが 木材にめり込む面積が異なることはよく知られている。ここでは、ボルト材 軸方向にボルトが木材にめり込む部分の有効長さを $t C$ として、以下扱う。

\section{2 .2 ボルトが木材を押し広げる面積のボルトの断面方向について} モデル化には次のようなに考えた。まず、破壊後及び破壊直前の状態を 図 19 (a) 及び(b)に示すように想定した。そして、図 19(c)に示すように、 破壊後の想定モデルを破壊直前のモデルに巻き戻しするために、破壊 後の想定モデルの端あき部を結合するための結合力を与えた。他方、図 19 (d) に示すように、破壊直前の想定モデルを破壊後のモデルにコマ送 りするために、破壊直前の想定モデルのボルト部に割裂き力を与えた。 そして、力の釣合い条件より、結合力の総和と割裂き力が釣り合わなけれ ばならない。すなわち、図 19 の(d)に示す割裂き力は、図 19 の (c) に示 す結合力と同じと考える。この結合力は、図 19 の (c)を図 19 の (b) にする 過程において、丸鋼に木材を繊維直角方向に押しつけてめり込ませ、左 右それぞれにボルトの断面積の半分ずつを繊維直角方向に押しのける のに必要な抵抗力と近似出来ると考えた。

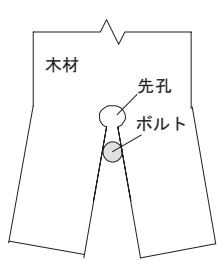

(a)

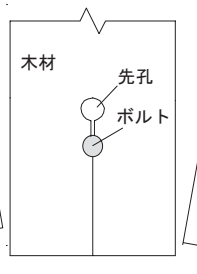

(b)

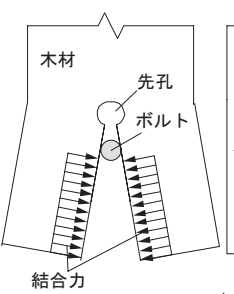

(c)

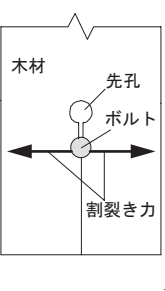

(d)

図 19 押し広げによる割裂破壊モデル

モデル化にあたり、ボルトが木材を繊維直角方向に押しのける体積、 すなわちボルトと木材が接している部分を以下のように考える。図 20 に、 
本論文でのモデル概念図を示す。ボルトと木材が接している部分は、弧 GG' と考えた。図 17 の特徽的な割裂破壊写真に示寸ように、図 20 の領 域 J にあたる部分の木材は過度のめり込みを受けているために大きな残 留変形が残っているものと考えられる。もっとも単純化して、図20の領域 J に示すように、ボルトが木材を繊維直角方向に押しのけた分全てが残留 変形として残っていると考えた。

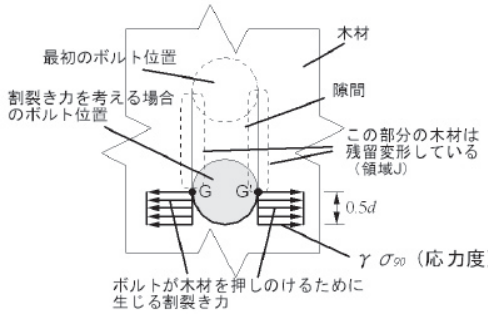

(a)

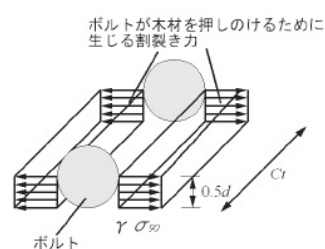

(b)
図 20 押し広げる面積の考え方

丸鋼を木材の繊維直角方向に押しつけてめり込ませるときに生じ る抵抗力は、抵抗機構が若干異なるが、信頼できるデータや評価式 が整備されている繊維直角方向の面圧性能で代用できるとして以下 導く。 $\gamma$ を繊維直角方向の面圧降伏応力度に対するボルト半径だけ めり込ます場合の面圧抵抗応力度の比とする。そうすると、割裂き 力 $P_{t}$ は以下の式で表現出来る。

$$
P_{t}=\gamma \cdot \sigma_{90} \cdot \frac{d}{2} \cdot t \cdot C \quad \cdots(31)
$$

次に、 $\gamma$ について考える。図 21 に木質構造設計ノート ${ }^{21)}$ の面圧 特性モデルを用いて算出した $\gamma$ とめり込み変位との関係を示す。こ の図から、半径分めり込む時の面圧抵抗応力度は、面圧降伏強度の 約二倍と考えられ、 $\gamma=2$ とした。つまり、式(31)は式(32)として表わ される。

$$
P_{t}=\sigma_{90} \cdot d \cdot t \cdot C \quad \cdots(32)
$$

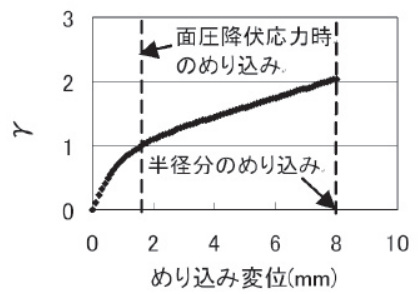

図 $21 \quad \gamma$ とめり込み変位との関係

ただし、 $\gamma$ : 半径分のめり込み変位時の面圧抵抗応力度に対する面圧降 伏応力度(木質構造設計ノートの面圧特性モデルを用いて算出)

ここで、接合部に作用する力 $P$ について考える。接合部が降伏し ている状態を想定しているので、接合部に作用寸る力 $P$ は、面圧強 度 $\sigma_{0}$ とボルト材軸方向にボルトが木材にめり込む部分の有効長さ を $C$ を用いて、以下のように表せる。

$$
P=\sigma_{0} \cdot d \cdot t \cdot C \quad \cdots(33)
$$

つまり、接合部に働く力 $P$ と割裂き力 $P_{t}$ の関係は以下のようになる。

$$
\frac{P_{t}}{P}=\frac{\sigma_{90} \cdot d \cdot t \cdot C}{\sigma_{0} \cdot d \cdot t \cdot C}=\frac{\sigma_{90}}{\sigma_{0}}
$$

割裂き力による摩擦を考慮し、摩擦係数を 0.3 とすると式(35)は以 下のようになる。

$$
\frac{P_{t}}{P}=\frac{\sigma_{90}}{1.3 \sigma_{0}}
$$

\section{2.3 割裂きカが作用した場合の木材の割裂破壊モデル}

図 22、図 23 に押し広げによる割裂破壊のモデルを示す。まず、初期 状態及び割れが $\Delta \beta$ 進展した状態を想定する。実験観察から、加力負担 側に先に割れが生じ、その後非加力負担側に割れが生じる場合が多か ったため、加力側の端あき部が割裂き力すべてを負担すると考える。つま り、加力側に割裂が生じる荷重が接合部の終局強度と考える。初期状態 としては、めり込みは進んでいるが割れが入っていない状態を考える。

まず、割れが進展する前の初期状態のモデル化を行い、 $P_{t}$ が働く位置 での変形を算出する。図 22 の幾何学関係を用いて等価な両端固定の梁 の曲げ変形とせん断変形を考慮すると、加力部の変位は式(36)で表せる。 なお、右辺の第一項は曲げによる変位を、右辺の第二項はせん断による 変位を表している。

$$
\delta_{1}=\frac{\left(\frac{d}{4}\right)^{3} P_{t}}{12 E I}+\frac{\kappa\left(\frac{d}{4}\right) P_{t}}{G e_{e} t} \quad \cdots(36)
$$

ただし、 $d$ : ボルトの直径、 $I$ : 等価梁置換した場合の断面二次モー メント、 $E$ : ヤング係数、 $e_{e}$ : 縁距離、 $t$ : 材幅、

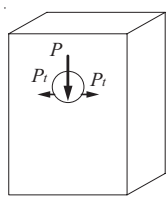

(a) 想定モデル

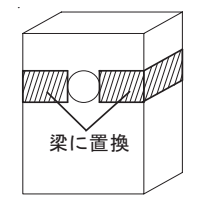

(b) 梁モデル

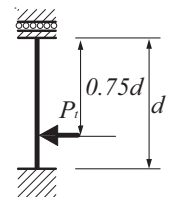

(c)力学モデル
図 22 割れが入る前の初期状態の想定モデルと力学モデル

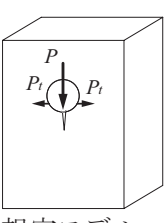

(a) 想定モデル

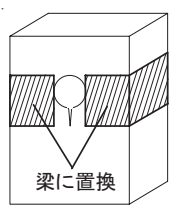

(b) 梁モデル

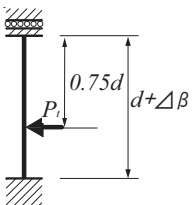

(c)力学モデル
図 23 割れが $\Delta \beta$ 進展した場合の想定モデルと力学モデル

初期状態から割れが $\Delta \beta$ 進展した状態のモデル化を行い、 $P_{t}$ が働く位 置での変形を算出する。この場合も同様に図 23 (c) の幾何学関係を用い て等価な両端固定の梁の曲げ変形とせん断変形を考慮すると、割れが $\Delta \beta$ 進展した場合の加力部の変位は式(34)で表せる。

$$
\delta_{2}=\frac{\left(\frac{d}{4}+\Delta \beta\right)^{3} P_{t}}{12 E I}+\frac{\kappa\left(\frac{d}{4}+\Delta \beta\right) P_{t}}{G e_{e} t}
$$

式 (1)、（36）、（37）を連立させ整理すると、割裂き力 $P_{t}$ が抵抗しう る強度を式(38)として導出できる。

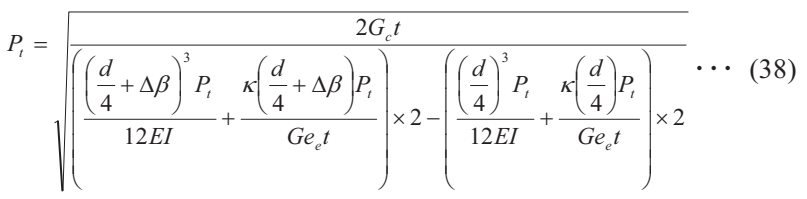

現実的な寸法を考えると、曲げ変形はせん断変形と比べて無視できる 程度に小さいと考えられ、簡易化のため曲げ変形成分を省略すると、以 下になる。

$$
P_{t}=\sqrt{\frac{2 G_{c} t}{\frac{2 \kappa \Delta P_{t}}{G e_{e} t}}}=t \sqrt{\frac{e_{e} G G_{c}}{\kappa}}=t \sqrt{0.83 e_{e} G G_{c}} \quad \cdots \text { (39) }
$$

\section{2.4 押し広げによる割裂破壊の強度算定式の導出}

ボル卜接合部に作用寸る力 $P$ と割裂き力 $P_{t}$ の関係から、押し広げによ 
る割裂破壊の強度算定式は式(40)として導出できる。

$$
P=\frac{1.3 \sigma_{0}}{\sigma_{90}} t \sqrt{0.83 G \cdot e_{e} G_{c}}=2.6 t \sqrt{0.83 G \cdot e_{e} G_{c}}
$$

\section{7. 木質鋼板単体ボルト接合の繊維方向に対する提案強度算定法}

\section{1 提案強度算定式}

接合部の強度は、各クライテリアの最小值とすべきかもわからないが、 押し広げによる割裂破壊は、接合部が降伏することを前提にモデル化を している。そのため、接合部の強度は以下のように算定する。

EYT 式より小さい場合:

$$
P=\min \left(P_{1}, \quad P_{2}, \quad P_{3}\right) \quad \cdots(41)
$$

EYT 式より大きい場合：

$$
\begin{aligned}
& P=\min \left(P_{1}, \quad P_{2}, \quad P_{3}, \quad P_{4}\right) \\
& P_{1}=2 \cdot e_{h} \cdot t \cdot \tau, \quad P_{2}=\frac{4 \cdot t \cdot e_{h}{ }^{2} \cdot \sigma_{90}}{3 \cdot d} \\
& P_{3}=\frac{t \sqrt{1.16 G \cdot e_{e} G_{c}}}{0.341}, \quad P_{4}=2.6 t \sqrt{0.83 G \cdot e_{e} G_{c}}
\end{aligned}
$$

ただし、 $\rho$ : 密度、 $G$ : せん断弾性係数、 $\sigma_{90}$ : 横引張強度、 $\tau$ : せん 断強度、 $e_{e}$ : 縁距離、 $e_{h}$ : 端距離、 $t$ : 材幅

\section{2 計算に用いた材料常数}

JIS の木材のせん断試験法を用いてせん断実験を行った結果、8MPa が得られた。また、 3 点曲げの横引張試験を行った結果 $2.2 \mathrm{MPa} の$ 值が 得られた。ヤング係数 $E$ は $6.5 \mathrm{GPa}$ 、せん断弾性係数は AIJ 規準に準じ てE/15を用いた。んは形状係数で 1.2 とした。破壊勒性值 $\left(G_{f}\right)$ は以下の 回帰式から算定し、 $0.24 \mathrm{kN} / \mathrm{mm}^{1.5}$ を用いた。

$$
G_{f}=-162+1.07 \rho \quad \cdots(43)
$$

\section{8. 検証実験}

\section{1 実験方法}

ボル卜接合部の端距離を $1 d 、 2 d 、 4 d 、 6 d 、 7 d$ 、縁距離を $1 d 、 2.5 d$ 、 $4 d 、 7 d 、 10 d$ 径長比を $0.625 d 、 0.375 d 、 7.5 d 、 10 d$ と変化させて実験を行 った。試験体には E 65 のスギ集成材を用いた。ボル卜は SS400 とした。各 条件 2 体ずつ、合計 160 体行った。平均含水率は、約 $11 \%$ \%゙あた。 加力は、単調加力で行った。变位の計測は、添え板鋼板と木材との相対 変位をこの接合部のすべり量と定義した。

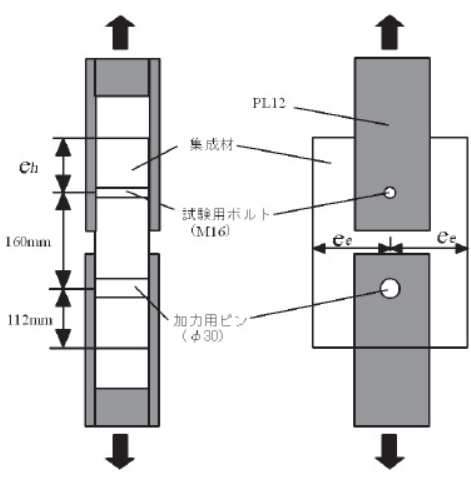

図 24 実験方法

\section{2 実験結果と理論值との比較}

実験結果と理論值との比較を通して、提案算定式を評価式として用い るときの注意点及び、現象を説明するモデルとして説明しきれていない点 を検討する。まず、評価式として考えた場合の適応範囲及び誤差に焦点 を当てる。図25に実験值と理論值の比較を示す。図25(a)に示寸実験で

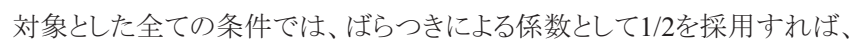

実験值が上限值及び下限值内に分布することがわかる。図 25 (b) に示寸 木質構造設計基準での適応範囲 (縁距離 $4 d$ 以上、端距離 $7 d$ 以上) の場

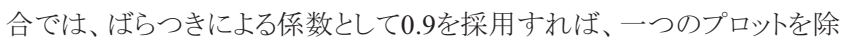
けば算定值がほぼ下限值を抑えていることが分かる。図25(c) に示寸ボ ル下配置基準と比べて極端に小さい条件(端距離 $2 d$ 以下、縁距離 $1 d$ )を 除外してまとめた場合では、ばらつきによる係数として3/4を採用すれば、 上限值及び下限值をおおむね㸚にらえる事が出来る。なお、実験值が理 論值より大きくなっている3つのプロットは、木質のボル卜接合部特有のい わゆるロープ効果 (ボル卜接合部の変形が $10 \mathrm{~mm}$ から $20 \mathrm{~mm}$ 以上と過度に大 きな場合に作用する大変形問題に起因する終局耐力の増大効果) によ るもので、設計值としての評価には、慎重に扱うべき効果であり、余力と 考える。つまり、本提案算定式の適応範囲は、樹種はスギ、ボルト径が $16 \mathrm{~mm}$ 、縁距離は $2.5 d か ら 7 d$ 、端距離は $2 d か ら 10 d の$ 場合、ばらつき係数 を3/4とすると上限值、下限值を抑えられる。樹種はスギ、ボル卜径が $16 \mathrm{~mm}$ 、縁距離は $1 d$ から $7 d$ 、端距離は $1 d$ から $10 d$ 場合、ばらつき係数を $1 / 2$ とすると上限值、下限值を抑えられる。樹種はスギ、ボル卜径が $16 \mathrm{~mm} 、$ 縁距離 $4 d$ 以上、端距離 $7 d$ 以上の場合、ばらつき係数を 0.9 とすると下限 值を抑えられる可能性があるが、更なる検討が必要である。今後、樹種、 ボル卜径等、実験による検証で適応範囲の幅を広げる事が課題である。

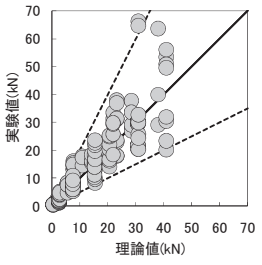

(a)全ての実験条件 の場合
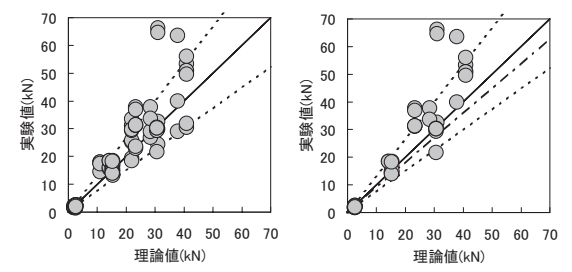

（b）縁距離 $4 \mathrm{~d}$ 以上 (c) 縁距離は $2.5 \mathrm{~d}$ 的 $7 \mathrm{~d}$ 端距離 $7 \mathrm{~d}$ 以上の場合 端距離は $2 d$ 以上の場合 図25 実験結果と算定值の比較

ただし、○: 実験值、(---) : (算定值 $) \times \pm 3 / 4 、(-・)$ : (算定值 $) \times 0.9$ 討する。罒26から28に、横軸をそれぞれ径長比、縁距離、端距離としてま とめ直した実験結果と提案算定式の計算值を示す。実験值は実験によっ て得られた最大耐力を示す。理論值は式(41)、(42)での算定值を示す。 なお、図28には比較のため、EYT式での算定值も示す。これらの図より、 本報告の提案算定式が、実験結果をある程度の精度で推定できることが 分かった。しかし、パラメータによってはかなり誤差のあるものとがある。た とえば、図27を見ると、径長比 $3.75 d$ 、縁距離 $1 d$ 場合には、端距離が $2 d$ を越えたあたりから実験值が理論值をかなり上回っている。一方、径長比 が7.5d、あるいは10 dの場合には、縁距離にかかわらず、端距離が小さ なところで実験值は理論值よりもかなり小さな值になっている。端距離が 小さなところで危険側の評価になっていることがわかる。これは、端あき部 の曲げ破壊モデル $P_{2}$ のモデル化に起因すると考えている。モデル化では、 部材の幅(ボルトの材軸)方向での応力分布が一様であるとして扱い、 $P_{2}$ の算定式では $t$ 比例するとしている。しかし、実現象では、荷重の小さな 弾性域であっても、弾性変形が起こり、部材の幅(ボルトの材軸)方向での 応力分布が一様にならず、材の両縁で応力集中が生じるとも考えられる。 これらについては、今後の課題である。

\section{9. まとめ}

本研究では、縁距離・端距離・径長比をパラメータとした木質ボル卜接 
合単体(繊維方向加力)の割裂破壊を主とした破壊強度算定式を式(39)、 式(40)として提案した。実験結果により妥当性を確認した。また、本提案 算定式を評価式として用いる場合の適応範囲とばらつき係数については、 樹種はスギ、ボルト径が $16 \mathrm{~mm}$ において、縁距離は $2.5 d$ から $7 d$ 、端距離 は $2 d$ から $10 d$ の場合はばらつき係数を $3 / 4$ に、縁距離は $1 d$ から $7 d$ 、端 距離は $1 d$ から $10 d$ の場合はばらつき係数を $1 / 2$ に設定することで上限值、
下限值を抑えることができる。縁距離 $4 d$ 以上、端距離 $7 d$ 以上の場合ばら つき係数を 0.9 と寸ると下限值を抑えられる可能性がある。

\section{謝辞}

本研究は、工学院大学学術フロンティア(宮澤健二代表)及び東京工 業大学統合研究院(和田章代表)の援助を受けた。ここに謝意を示す。

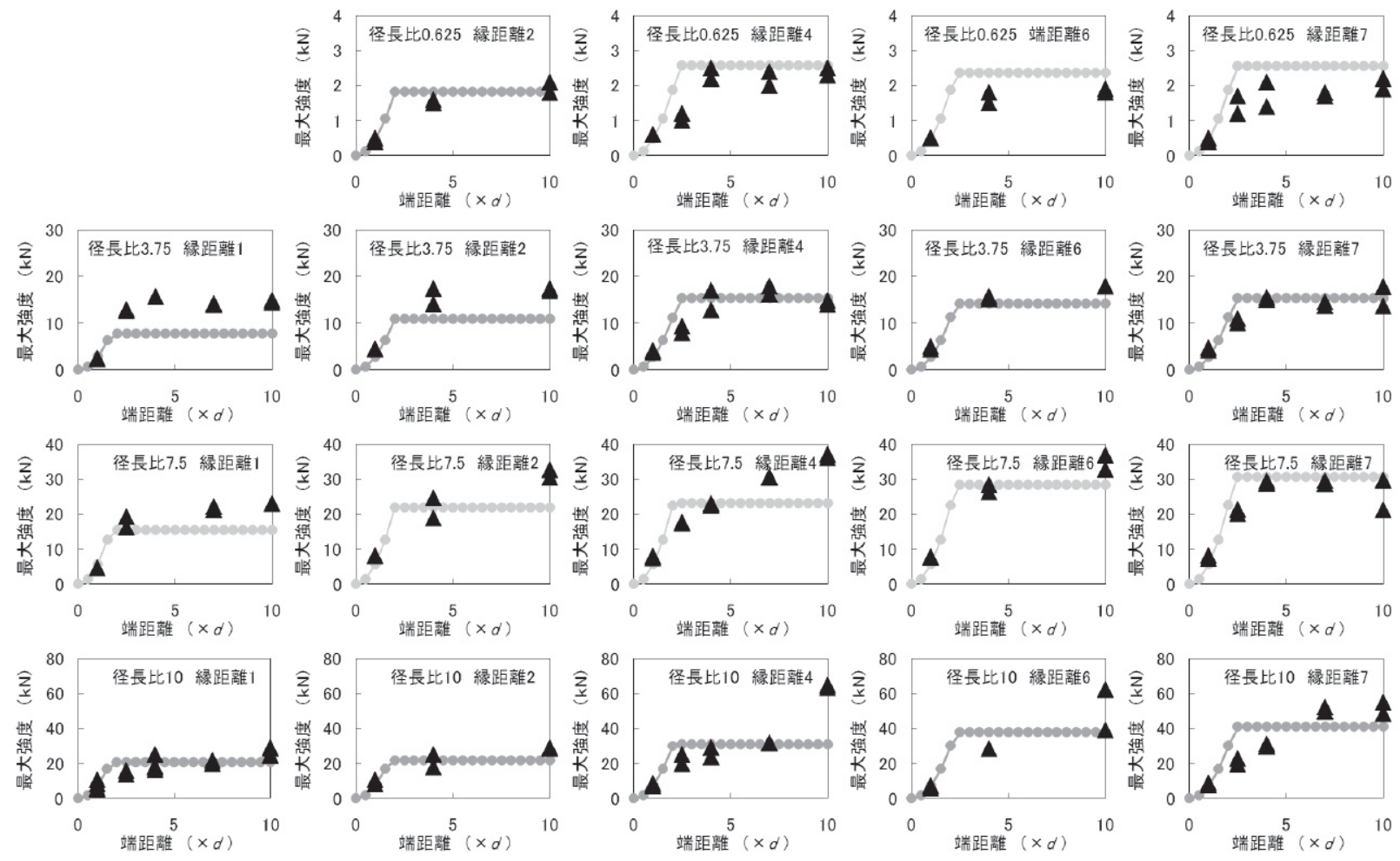

図 26 横軸を端距離ししてまとめ直した実験結果と提案算定式の計算值(ただし、 $\boldsymbol{\Delta}$ : 実験值、線: 算定值)
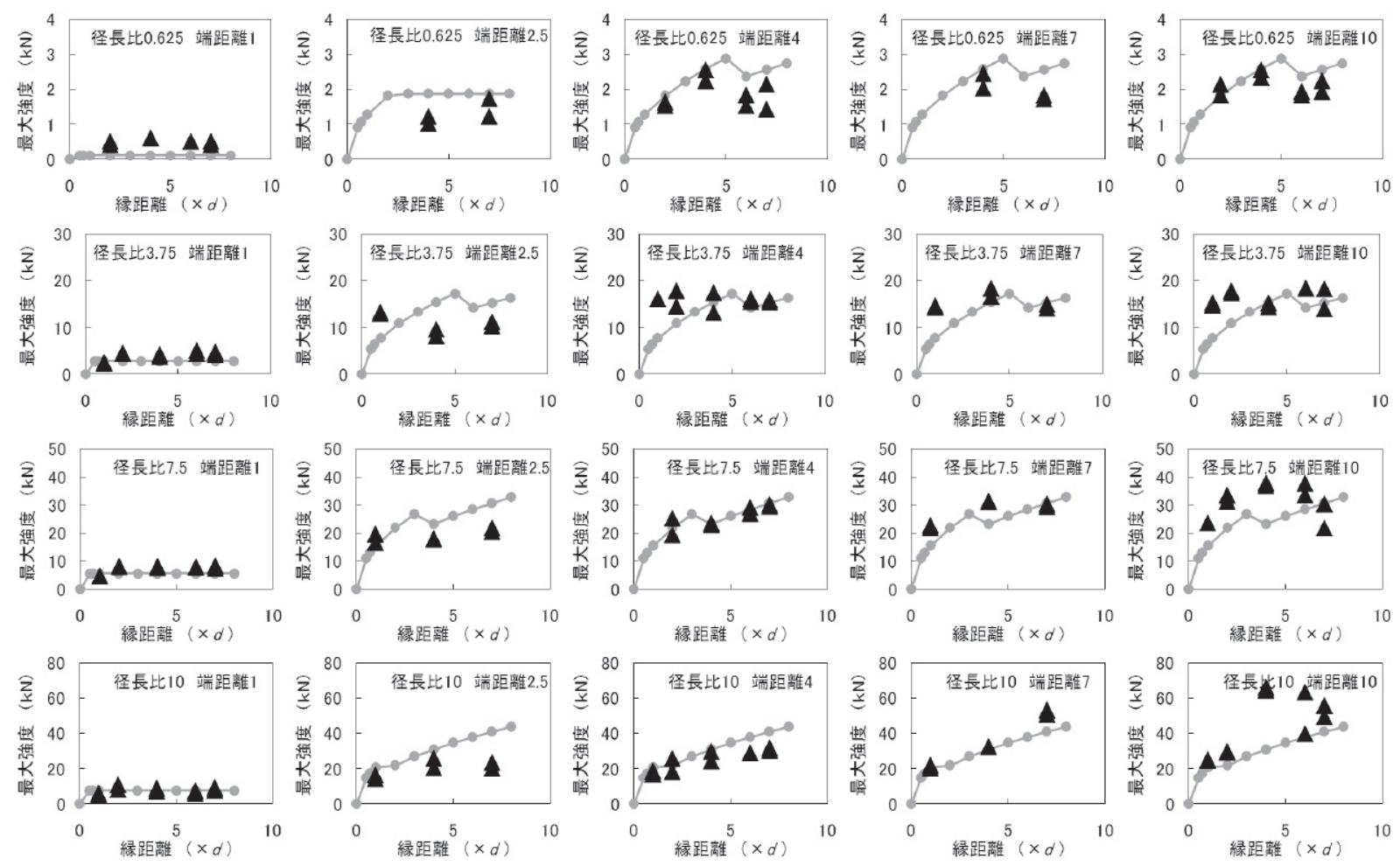

図 27 横軸を縁距離としてまとめ直した実験結果と提案算定式の計算値(ただし、ム : 実験值、線: 算定値) 

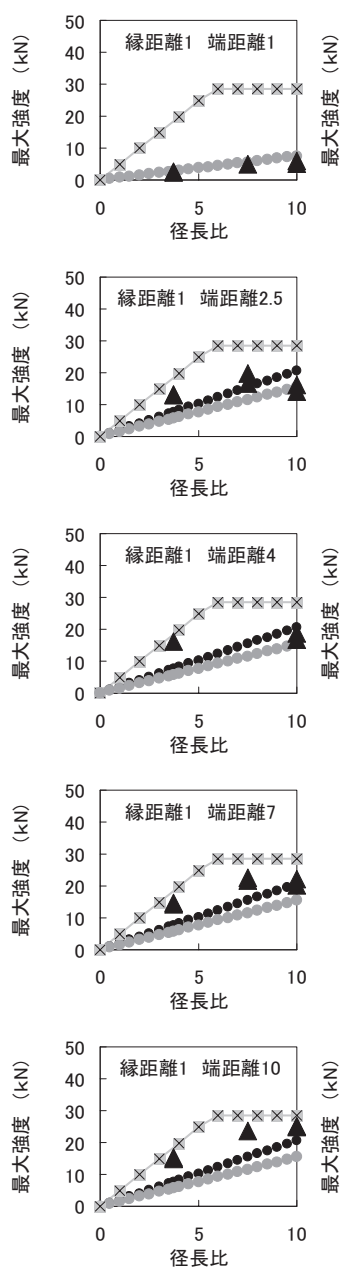
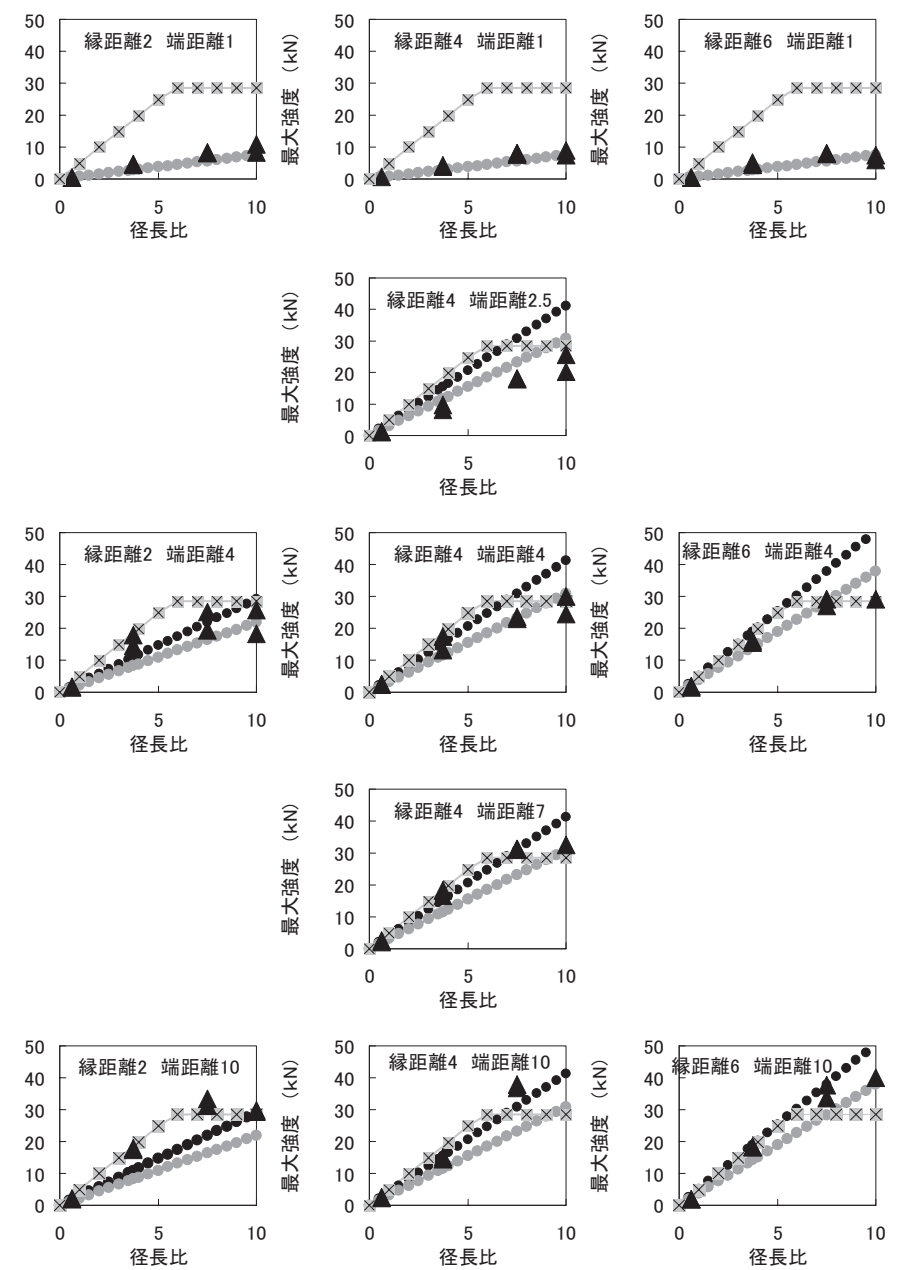
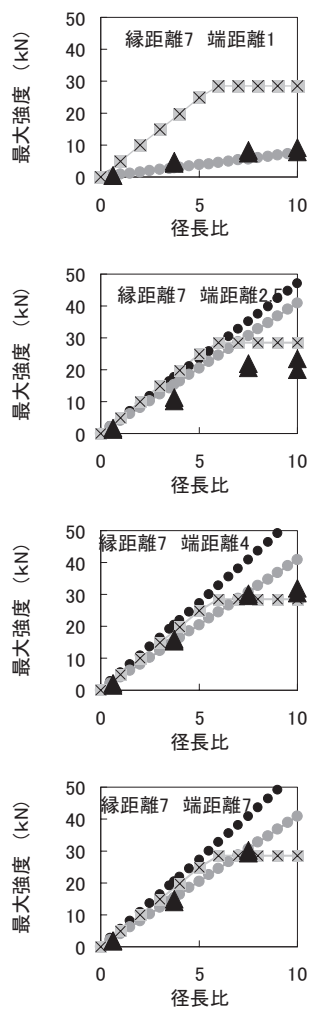

図 28 横軸を径長比としてまとめ直した実験結果と提案算定式の計算値

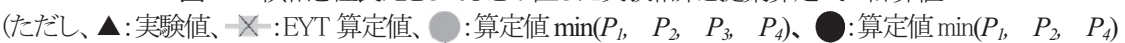

\section{参考文献}

1) 日本建築学会:木質構造設計規準、丸善、東京、 2006

2) Johansen K.W. :Theory of timber connection, International Association for bridge and structural Engineering, nr. 9, pp. 249-262, 1949

3) 桑村 仁: 切欠き木材梁の割裂応力度 一鉄骨木質構造の研究 その1-, 日本 建築学会構造系論文集 No.619, pp.111-118, 2007.9

4)神戸 渡, 中込忠男, 伊倉裕太:繊維直交方向荷重を受けるカラマッ集成材ボル卜 接合部の脆性破壊に対寸るローカルクライテリアの適用, 日本建築学会構造系論 文集 No.611, pp.111-118, 2007.1

5)神戸 渡, 飯島泰男, 中込忠男: 構造用集成材木材を対象としたモード I 破壞勒 性性能の評価方法に関する考察，日本建築学会構造系論文集 No.631， p. $1593-1598,2008.9$

6) Jorissen, A.J.M.: Double shear timber connections with dowel type fasteners, Ph-D thesis, Delft University of Technology,1998

7) Heine, C.P.:Cyclic Response of Multiple-Bolt Connections, PhD Dissertation, Wood Science and Forest Products Department, Virginia Polytechnic Institute and State University, Blacksburg, Virginia, August 2001

8) Masuda, M., and Tabata, K. : Theoretical and experimental analyses of fracture of wood in pinned joint using DIC and FSAFC. Proc. of RILEM Symposium, PRO 22, Stuttgart Germany,12-14 September, pp. 3-12, 2001

9) D Tan, I Smith:Failure In-the-Row Model for Bolted Timber Connections, J. Struct. Engrg. Vol. 125(7), pp. 713-718, 1999

10) van der Put, T.A.C.M., and Leijten, A.J.M.: Evaluation of perpendicular to grain failure of beams caused by concentrated loads of joints. Proc. of CIB-W18 Paper 33-7-7

11) H Petersson:On Design Criteria for Tension Perpendicular to Grain, Proc. of CIB-W18 Paper, 25-6-4

12) J. L. Jensen: Splitting strength of beams loaded perpendicular to grain by dowel joints、 Vol. 51, (5)、pp. 480-485, 2005.10

13) P J Gustafsson:A Study of Strength of Notched Beams, Proc. of CIB-W18 Paper, 21-10-1

14) 木内石:機械設計便覧(新版)、日刊工業新聞社、東京、1976、pp.185-186

15)Y Murase: Friction of wood sliding on various materials, J Fac Agric Kyushu Univ, 1984,pp. $147-160$

16) 林知行, 江越航,軽部正彦, 原田真樹:木質構造接合部における摩擦(1)、日本木 材学会大会要旨集、49 号、pp.246、1999

17）日本住宅・木材技術センター:木造軸組工法住宅の許容応力度設計、日本住 宅・木材技術センター、2001

18) Kuenzi 、 E.W.: Report D.1951、 F.P.L. Madison、 1955

19) 原田正道: 木船の縦強度、東京大学生産技術研究所報告, vol.2(3).1951.

20) 森林総合研究所監修: 木材工業ハンドブック(改定第 3 版)、丸善、1982、pp.130

21）日本建築学会:モーメント抵抗接合、木質構造設計ノート pp.184-221,1994

\section{APPENDIX FEM 解析}

付図 1 に要素分割と境界条件を示す。線形応力解析を行った。樹種 はスギとした。材料定数は、木材工業ハンドブックを参考に決めた。 木材は 4 節点平面要素で表現した。付図 1 (b) に示すボルト周辺は、 ボルト穴の円を 360 分割した。付図 1 (a) の板の X 方向を 40 分割、Y 方向を 60 分割した。（節点は 15964 点、要素数は 13850 個）。

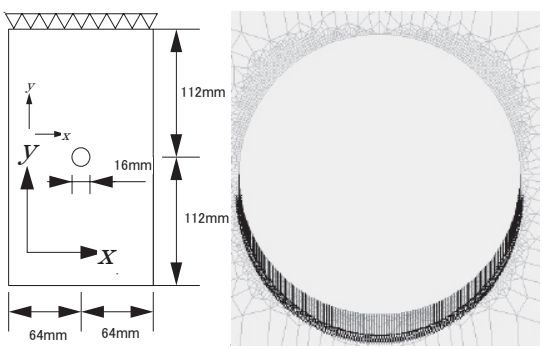

（a）全体と境界条件（b) ボルト周辺と荷重条件 付図 1 要素分割と境界条件 